\title{
Emulsified Isoflurane Preconditioning Reduces Lung Injury Induced By Hepatic Ischemia/Reperiusion in Rats
}

\section{Xin Lv ${ }^{1,2}{ }^{*}$, Zhen-meng Wang ${ }^{1 *}$, Sheng-dong Huang ${ }^{3}$, Shao-hua Song ${ }^{4}$, Fei-xiang Wu1 ${ }^{1}$, Wei-feng $\mathrm{Yu}^{1 \bowtie}$}

1. Department of Anaesthesia and Intensive Care, Eastern Hepatobiliary Surgery Hospital, Second Military Medical University, Shanghai, China.

2. Department of Anesthesiology, Shanghai Pneumology Hospital, Tongji University School of Medicine, Shanghai, China.

3. Department of Cardiothoracic surgery, Changhai Hospital, Second Military Medical University, Shanghai, China.

4. Organ Transplantation Center, Changzheng Hospital, Second Military Medical University, Shanghai, China.

* The first two authors contributed equally to this work.

$\triangle$ Corresponding author: Wei-Feng Yu, Prof., Department of Anesthesia and Intensive Care, Eastern Hepatobiliary Surgery Hospital, Second Military Medical University, 225\# Changhai Road, Shanghai 200438, China. Telephone and Fax: +86-21-81875231. E-mail: ywf808@sohu.com.

(C) Ivyspring International Publisher. This is an open-access article distributed under the terms of the Creative Commons License (http://creativecommons.org/ licenses/by-nc-nd/3.0/). Reproduction is permitted for personal, noncommercial use, provided that the article is in whole, unmodified, and properly cited.

Received: 2010.12.27; Accepted: 2011.04.11; Published: 2011.06.08

\begin{abstract}
Objective: To investigate whether emulsified isoflurane preconditioning could reduce lung injury induced by hepatic I/ $\mathrm{R}$ in rats and its mechanism.

Materials and methods: 32 pentobarbital-anesthetized Sprague-Dawley rats were equally randomized into four groups: laparotomy group (Sham group), hepatic I/R and normal saline infusion group (I/R+S group), I/R and lipid vehicle infusion (I/R+V group), or $\mathrm{I} / \mathrm{R}$ and $8 \%$ emulsified isoflurane infusion (I/R+E group) at the rate of $8 \mathrm{ml} \mathrm{kg}^{-1} \cdot \mathrm{h}^{-1}$ for 30 min. Blood supply of the hepatic artery and portal vein to the left and the median liver lobes was occluded for $90 \mathrm{~min}$ after 30-min washout time. Reperfusion was allowed to proceed for $4 \mathrm{~h}$ before sacrifice of the animals. Lung injury was observed histologically. Neutrophil infiltration and TNF-a concentration in serum and lung were measured. Changes of wet-to-dry weight ratios in lung tissue, ICAM-1 expression and NF-KB activity in lung after hepatic I/R were determined.

Results: Compared with $\mathrm{I} / \mathrm{R}+\mathrm{S}$ or $\mathrm{I} / \mathrm{R}+\mathrm{V}$ group, emulsified isoflurane preconditioning reduced hepatic I/R-induced lung histologic injury and inhibited the increase of myeloperoxidase (MPO) activity in the lung tissue markedly (5.5 \pm 1.37 and $5.22 \pm 1.33$ vs $3.81 \pm 1.62 \mathrm{U} / \mathrm{g}, \mathrm{P}<0.05)$. In addition, both serum and lung tissue TNF-a levels were reduced in I/R+E group $(104.58 \pm 31.40$ and $94.60 \pm 22.23$ vs $72.44 \pm 17.28 \mathrm{pg} / \mathrm{ml}, \mathrm{P}<0.05$; $393.51 \pm 88.22$ and $405.46 \pm 102.87$ vs $292.62 \pm 74.56 \mathrm{pg} / \mathrm{ml}, \mathrm{P}<0.01)$. Emulsified isoflurane preconditioning also inhibited the increase of ICAM-1 expression $(0.79 \pm 0.17$ and $0.84 \pm 0.24$ vs $0.62 \pm 0.21, \mathrm{P}<0.05)$ and NF-KB translocation $(4.93 \pm 0.48$ and $4.76 \pm 0.57$ vs $4.01 \pm 0.86, \mathrm{P}<0.05)$ in the lung tissue markedly.

Conclusions: Emulsified isoflurane preconditioning markedly attenuated hepatic I/R-induced lung injury in rats, which may be hopefully applied to the clinical treatment of organ injury caused by hepatic surgery, transplantation or hemorrhagic shock.
\end{abstract}

Key words: emulsified isoflurane; inflammation; intercellular adhesion molecule-1; neutrophils; nuclear factor- $\mathrm{kB}$; rats; tumor necrosis factor- $\alpha$ 


\section{Introduction}

Ischemia/reperfusion (IR) injury represents a complex series of events, including release of reactive oxygen species, nitric oxide imbalance, cytokine cascades, neutrophil accumulation and cell death, resulting in cellular and tissue damage ${ }^{1}$. Hepatic I/R injury, which can been seen in various clinical settings such as liver transplantation, hepatectomy, and hemorrhagic shock, may lead to local and remote organ damage ${ }^{2}$, yet the precise pathogenesis is not fully defined. Massive accumulation of neutrophils in the lung, the development of interstitial pulmonary edema and increased expression of proinflammatory mediators are major features of lung injury induced by hepatic I/R.

Various methods, including pharmacological treatment, gene therapy and ischemia preconditioning, have been applied to ameliorate hepatic I/ $\mathrm{R}$ injury, with inspiring results. In 1986, Murry et $\mathrm{al}^{3}$ demonstrated for the first time that intermittent episodes of ischemia had a protective effect on the myocardium that was later subjected to a sustained bout of ischemia. A characteristic of ischemic preconditioning is a cross-tolerance phenomenon. The efficacy of anesthetic preconditioning was first described in 1997 with isoflurane in animals ${ }^{4,5}$, and later confirmed by several studies in the brain ${ }^{6}$, kidney $^{7}$ and liver ${ }^{8}$. Inhaled isoflurane preconditioning was also shown to reduce acute lung injury and inflammation induced by endotoxin ${ }^{9,10}$ or I/R $\mathrm{R}^{11}$.

Emulsified isoflurane has been widely studied in recent years, because it was found to eliminate the need for specific ventilatory circuits, provide rapid anesthetic induction and recovery, have remarkable hemodynamic stability ${ }^{12}$ and reduce environmental pollution and tissue toxicity. Rao et $\mathrm{al}^{13}$ demonstrated that emulsified isoflurane had a myocardial protective effect on I/R injury similar to that of inhaled isoflurane. We therefore hypothesized that emulsified isoflurane preconditioning might also be able to inhibit inflammation reaction and reduce lung injury induced by hepatic I/ $R$ in rats.

\section{Materials and methods}

Inbred male Sprague-Dawley rats weighing 200-250 g (Experimental Animal Center of the Second Military Medical University, Shanghai, China) were maintained in laminar flow cages in a specific pathogen free animal facility, and allowed free access to standard laboratory chow and water before experiments. This study was approved by the animal care committee at the Second Military Medical University and all procedures in this experiment were performed according to the Guide for the Care and Use of Laboratory Animals.

\section{Surgical procedures of hepatic I/R}

A model of segmental $(70 \%)$ hepatic ischemia was used as previously described ${ }^{14,15}$. Rats were anesthetized intraperitoneally with pentobarbital (40 $\mathrm{mg} / \mathrm{kg}$ ). Body temperature was monitored by a rectal probe and maintained at around $37^{\circ} \mathrm{C}$ by a heating lamp. The right carotid artery was cannulated for arterial blood monitoring and blood-gas analysis, and the right jugular vein was cannulated for drug infusion and blood sampling. A midline laparotomy was performed, and an atraumatic clip was applied to interrupt the arterial and portal venous blood supply to the left and median lobes of the liver. The clip was removed $90 \mathrm{~min}$ after partial hepatic ischemia to initiate hepatic reperfusion. Sham control rats underwent the same protocol without vascular occlusion. Oxygen was not given during the surgery and throughout the experimental period. Rats were killed after 4-h reperfusion, and lung tissues and blood samples were collected for analysis.

\section{Preparation of emulsified isoflurane}

The $8 \%$ emulsified isoflurane $(\mathrm{v} / \mathrm{v})$ manufactured by Huarui Pharmacy, Ltd (Wuxi, China) according to the procedures described previously ${ }^{16,17}$, was kindly bestowed by Prof. Jin Liu from the Laboratory of Anesthesiology and Critical Care Medicine, West China Hospital, Sichuan University (Chengdu, China). Briefly, $1.6 \mathrm{~mL}$ liquid isoflurane and $18.4 \mathrm{~mL}$ $30 \%$ Intralipid ${ }^{\circledR}$ (fat emulsion injection, Sino-Swed Pharmaceutical Corp. LTD, China) was mixed in a 20-mL glass ampoule and sealed using an alcohol blowtorch. The ampoule was then vigorously shaken on a vibrator for $15 \mathrm{~min}$ to solubilize isoflurane into a lipid emulsion. The emulsified isoflurane ampoule was opened just before use and the residual drug was discarded. Before this experiment, the stability of $8 \%$ emulsified isoflurane was investigated by gas chromatography. There was no change in isoflurane concentration nor were lipid droplets found during 6 months of storage at room temperature.

\section{Experimental Design}

Group 1. Sham $(n=8)$ : animals were subjected to anesthesia and laparotomy.

Group 2. I/ $R+S(n=8)$ : animals were infused with normal saline through the right external jugular vein at the rate of $8 \mathrm{ml} \mathrm{kg}^{-1} \mathrm{~h}^{-1}$ for $30 \mathrm{~min}$, and then subjected to $70 \%$ hepatic ischemia for $90 \mathrm{~min}$, followed by 4-h reperfusion. 
Group 3. I/ $\mathrm{R}+\mathrm{V}(\mathrm{n}=8)$ : animals were infused with lipid vehicle (Intralipid ${ }^{\circledR}, 30 \%$ ) through the right external jugular vein at the rate of $8 \mathrm{ml} \mathrm{kg}^{-1} \cdot \mathrm{h}^{-1}$ for 30 $\mathrm{min}$, followed by a 30 -min wash-out period before $\mathrm{I} / \mathrm{R}$.

Group 4. I/ $\mathrm{R}+\mathrm{E}(\mathrm{n}=8)$ : animals were infused with emulsified isoflurane through the right external jugular vein at the rate of $8 \mathrm{ml} \mathrm{kg} \mathrm{kg}^{-1} \mathrm{~h}^{-1}$ for $30 \mathrm{~min}$ as Rao described ${ }^{13}$, followed by a 30-min wash-out period before I/R.

\section{Lung Function}

Before sacrifice of the animals, arterial blood was sampled from the right carotid artery for blood gas analysis with a blood-gas analyzer (GEM Premier 3000, Instrumentation Laboratory, USA).

\section{Histology}

The middle lobe of the right lung was excised for histopathology. Samples were fixed in 10\% neutral buffered formalin, paraffin embedded, sliced into $5-\mu \mathrm{m}$ sections, stained with hematoxylin-eosin (H\&E) according to standard procedures, and evaluated by light-microscopic examination.

\section{Pulmonary edema}

The extent of lung edema was measured by tissue wet to dry weight ratios. The lower lobe of the right lung from each animal was harvested, blotted dry, weighed, incubated at $60^{\circ} \mathrm{C}$ overnight and reweighed $^{18}$. The wet to dry weight ratio was calculated by dividing the wet by the dry weight.

\section{Myeloperoxidase assay}

Myeloperoxidase (MPO), a marker of pulmonary neutrophil accumulation and activation, was determined by a modified method of Welborn et $\mathrm{al}^{19}$. Briefly, frozen lung sample $(200 \mathrm{mg})$ was homogenized in $0.01 \mathrm{M} \mathrm{KH}_{2} \mathrm{PO}_{4}$ at a ratio of 1:10 weight for volume. The pellets were resuspended in $0.5 \mathrm{~mL}$ of C-TAB (cetyltrimethylammoniumbromide) buffer. The samples were homogenized, sonicated for $45 \mathrm{~s}$, and subjected to one freeze-thaw cycle. MPO was assayed in the supernatant with the $\mathrm{H}_{2} \mathrm{O}_{2}$-dependent oxidation of 3,3',5,5'-tetramethylbenzidine. Absorbance was read at $650 \mathrm{~nm}$ and compared with a linear standard curve with sensitivity to $0.008 \mathrm{U}$. Values were then divided by the wet weight of the lung tissue.

\section{Lung tissue and serum tumor necrosis factor-a (TNF-a) Assay}

Frozen lung tissue was homogenized in 10 volumes of $50 \mathrm{mmol} / \mathrm{L}$ phosphate buffer ( $\mathrm{pH}$ 6.0). After centrifugation at $4,000 \mathrm{~g}$, the supernatant was frozen at $-20^{\circ} \mathrm{C}$ and saved for measurement of TNF- $\alpha$ level. $2 \mathrm{ml}$ blood obtained from the right jugular vein was centrifuged at $3,000 \mathrm{~g}$ to get serum, which was saved at $-20^{\circ} \mathrm{C}$ for measurement of TNF-a levels. Lung tissue and serum TNF-a levels were measured using a commercial rat TNF-a ELISA kit (R\&D Systems, USA).

\section{RT-PCR analysis of intercellular adhesion mole- cule-1 (ICAM-1) mRNA expression in the lung}

ICAM-1 mRNA from frozen lung tissues was measured using semi-quantitative RT-PCR. Total RNA was extracted from the tissue sample using the Trizol reagent (Invitrogen, Life Technologies) according to the manufacturer's protocol. The RNA concentration was determined by ultraviolet light absorbance at a wavelength of $260 \mathrm{~nm}$. The first-strand complementary DNA (cDNA) was synthesized using oligo-dT primer and the AMV reverse transcriptase. The cDNA products were amplified in $50 \mu l$ reaction volume containing $50 \mathrm{pmol}$ of each primer, $1 \mu \mathrm{l}$ of the cDNA reaction mix, $5 \mu \mathrm{l}$ Buffer $(10 \mathrm{mmol} / \mathrm{L}), 1 \mu \mathrm{l}$ of each dNTP $(10 \mathrm{mmol} / \mathrm{L})$, and 3 units of Taq DNA polymerase (GIBCO Life Technologies). After 5-min initial melting at $95^{\circ} \mathrm{C}$, the mixture was amplified for a total of 30 cycles with a three-step cycle process that began with melting at $95^{\circ} \mathrm{C}$ for $45 \mathrm{~s}$, annealing at $60^{\circ} \mathrm{C}$ for $30 \mathrm{~s}$, and extension at $72^{\circ} \mathrm{C}$ for $45 \mathrm{~s}$. The final cycle was followed by 5 -min soaking at $72^{\circ} \mathrm{C}$. The nucleotide sequences of the PCR primers were 5'CTTCAAGCTGAGCGACATTGG -3' (forward) and 5'- AGCATGAGAAATTGGCTCCGT -3' (reverse) for ICAM-1 and 5'- ACCACAGTCCATGCCATCAC -3' (forward) and 5'- TCCACCACCCTGTTGCTGTA -3' (reverse) for GAPDH. The expected size of the amplified cDNA fragments of ICAM-1 and GAPDH was 326 and $452 \mathrm{bp}$, respectively. Ten microliters of each RT-PCR were electrophoresed in a $1.5 \%$ agarose gel and stained with ethidium bromide. The intensity of each ICAM-1 mRNA band was quantified by densitometry using a gel documentation and analysis system and normalized to values for GAPDH.

\section{Western blot analysis for nuclear factor- $\mathrm{kB}$ (NF-kB) activity}

Nuclear proteins were prepared from lung tissues according to the modified protocols of previously studies ${ }^{20,21}$. Briefly, frozen liver tissues were homogenized in cold buffer A containing $10 \mathrm{mM}$ HEPES-KOH, $1.5 \mathrm{mM} \mathrm{MgCl}, 10 \mathrm{mM} \mathrm{KCl}, 1 \mathrm{mM}$ phenylmenthysulfonylfluoride (PMSF), $1 \mathrm{mM}$ dithiothreitol(DTT) and $0.1 \mathrm{mM}$ EDTA. The homogenate was centrifuged at $450 \mathrm{~g}$ for $1 \mathrm{~min}$ at $4^{\circ} \mathrm{C}$. The supernatant was collected and incubated on ice for $30 \mathrm{~min}$, 
vortexed for $30 \mathrm{~s}$ after addition of $10 \% \mathrm{NP}-40$, then centrifuged at 5,000g for $3 \mathrm{~min}$ at $4^{\circ} \mathrm{C}$. The pellet (nuclei) was resuspended in cold buffer $\mathrm{B}$ containing 20mM HEPES-KOH, 25\% glycerol, $420 \mathrm{mM} \mathrm{NaCl}$, $1.5 \mathrm{mM} \mathrm{MgCl} 2,1 \mathrm{mM}$ PMSF, $1 \mathrm{mM}$ DTT, and $0.1 \mathrm{mM}$ EDTA, and incubated for $30 \mathrm{~min}$ with intermittent stirring. The suspension was centrifuged at $15,000 \mathrm{~g}$ for $10 \mathrm{~min}$ at $4^{\circ} \mathrm{C}$, and the protein concentration was determined by Coomassie blue dye-binding assay. An equal amount of protein was mixed with the sample buffer, separated by $10 \%$ SDS-PAGE, and transferred to nitrocellulose membranes. The membrane was blocked for $1 \mathrm{~h}$ at room temperature with blocking solution (3\% nonfat milk in Tris buffered saline with Tween 20). Blots were then incubated overnight at $4^{\circ} \mathrm{C}$ with mouse monoclonal anti-NF-kB p65 antibody (Santa Cruz Biotechnology, 1:500), washed three times, and incubated with a horseradish peroxidase-labeled secondary antibody for $1 \mathrm{~h}$ at room temperature. Immunoreactive proteins were visualized with the use of enhanced chemiluminescence detection (Pierce, USA). The protein band density was quantified by densitometric techniques and expressed as mean relative densitometric units.

\section{Statistical analysis}

Data were expressed as mean \pm SD. The statistical analysis was carried out using SPSS 13.0 for Windows. All data were analyzed by ANOVA, followed by the Student-Newman-Keuls test. $P<0.05$ was considered statistically significant.

\section{Results}

\section{Arterial blood gas analysis}

Compared with sham group, the IR+S and IR+V group had significantly lower $\mathrm{PaO}_{2}$ and higher $\mathrm{PaCO}_{2}$ $(\mathrm{P}<0.05)$. Preconditioning with emulsified isoflurane improved pulmonary function, as indicated with higher $\mathrm{PaO}_{2}$ and lower $\mathrm{PaCO}_{2}$, while $\mathrm{pH}, \mathrm{HCO}_{2}{ }^{-}$and $\mathrm{SpO}_{2}$ in IR+S and IR+V groups were lower than those in sham and IR+E groups, but the difference was not statistically significant $(\mathrm{P}>0.05$, Table 1$)$.

Table 1 Arterial blood gas analysis

\begin{tabular}{llllll}
\hline & $\mathrm{pH}$ & $\mathrm{PO}_{2}$ & $\mathrm{PCO}_{2}$ & $\mathrm{HCO}_{2}^{-}$ & $\mathrm{SPO}_{2}$ \\
\hline sham & $7.38 \pm 0.05$ & $91.38 \pm 3.67^{\mathrm{a}}$ & $37.25 \pm 2.05^{\mathrm{a}}$ & $25.56 \pm 1.67$ & $97.00 \pm 1.07$ \\
\hline $\mathrm{IR}+\mathrm{S}$ & $7.33 \pm 0.03$ & $80.50 \pm 6.78$ & $44.38 \pm 3.81$ & $22.70 \pm 2.99$ & $95.50 \pm 1.69$ \\
$\mathrm{IR}+\mathrm{V}$ & $7.33 \pm 0.06$ & $80.25 \pm 9.38$ & $42.38 \pm 3.54$ & $23.33 \pm 1.50$ & $95.13 \pm 1.96$ \\
\hline $\mathrm{IR}+\mathrm{E}$ & $7.39 \pm 0.03$ & $89.13 \pm 6.51^{\mathrm{a}}$ & $37.25 \pm 3.96^{\mathrm{a}}$ & $25.20 \pm 2.07$ & $96.63 \pm 1.19$
\end{tabular}

Data are expressed as mean $\pm \mathrm{SD}$. a $\mathrm{p}<0.05$ vs $\mathrm{I} / \mathrm{R}+\mathrm{S}$ group or $\mathrm{I} / \mathrm{R}+\mathrm{V}$ group.

\section{Lung histopathology after hepatic I/R}

The effects of emulsified isoflurane preconditioning on the histopathological changes of the lungs in rats with hepatic I/ $R$ are shown in Figure 1.

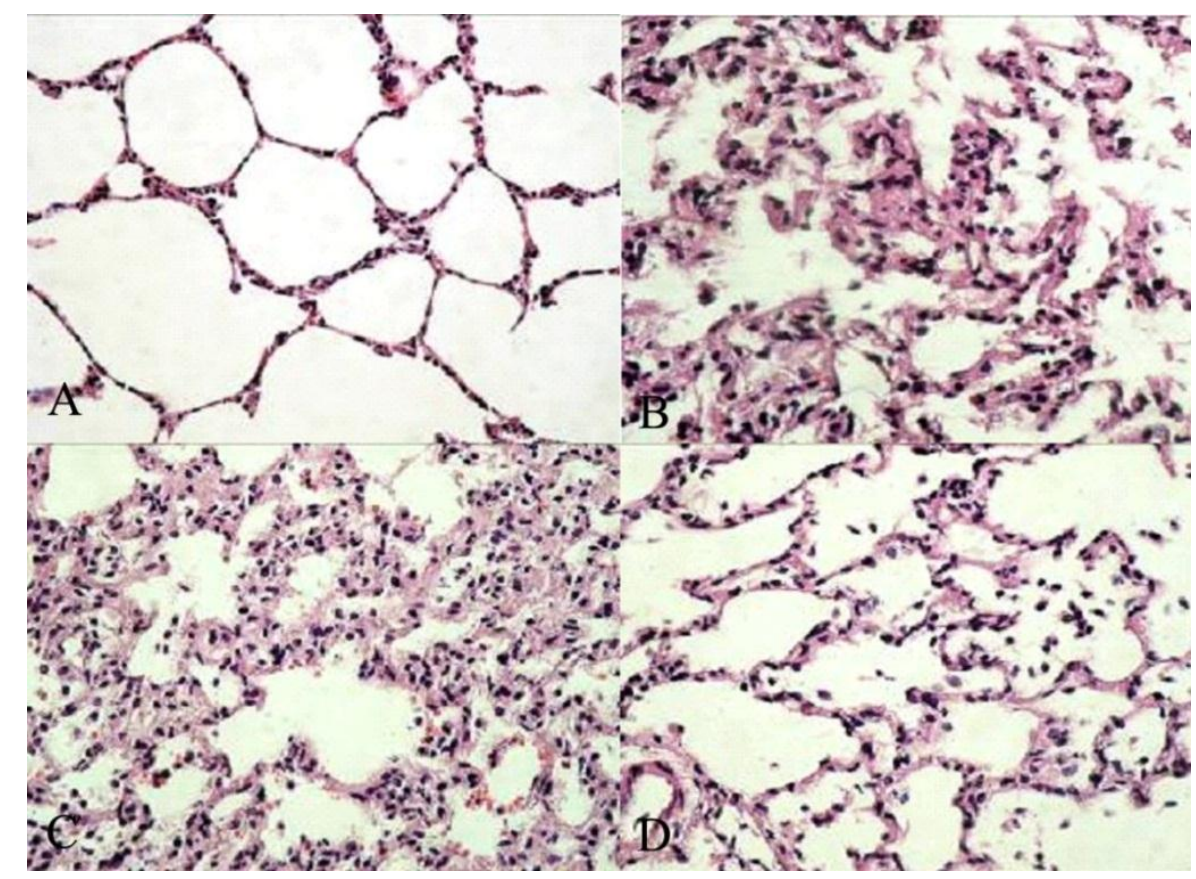

Figure 1: Morphologic changes of the lung. A, sham group: No histologic alteration was observed. $B, I R+S$ group: the inflammatory process was observed as represented by infiltration of leukocytes into interstitial and alveolar spaces, edema and partial destruction of the pulmonary architecture. $C, I R+V$ group: Similar to IR+S group $D$, IR+E group: Lung pathology was attenuated to a great extent. Original magnification: $\times 400$. 
Blind analysis was performed on all samples to evaluate pulmonary architecture, tissue edema formation and infiltration of the inflammatory cells. The results were classified into four grades where Grade 1 represented normal histopathology; Grade 2 mild infiltration of neutrophilic leukocytes; Grade 3 moderate infiltration of neutrophilic leukocytes with perivascular edema formation and partial destruction of the pulmonary architecture and Grade 4 dense infiltration of neutrophilic leukocyte associated with abcess formation and complete destruction of the pulmonary architecture. Pulmonary histology was normal in sham group (Grade 1, Fig. 1A). In contrast, morphological study showed that the lung tissues in the saline treated and fat vehicle treated groups were severely damaged $90 \mathrm{~min}$ after hepatic ischemia and 4 $\mathrm{h}$ after reperfusion, as represented by marked infiltration of leukocytes into interstitial and alveolar spaces, edema and partial destruction of the pulmonary architecture (Grade 3, Fig. 1B \& 1C), while only moderate lung edema, inflammatory cell infiltration and thickening of the alveolar wall were seen in emulsified isoflurane preconditioning group (Grade 2, Fig. 1D), suggesting that lung injury induced by hepatic I/R was attenuated by emulsified isoflurane preconditioning.

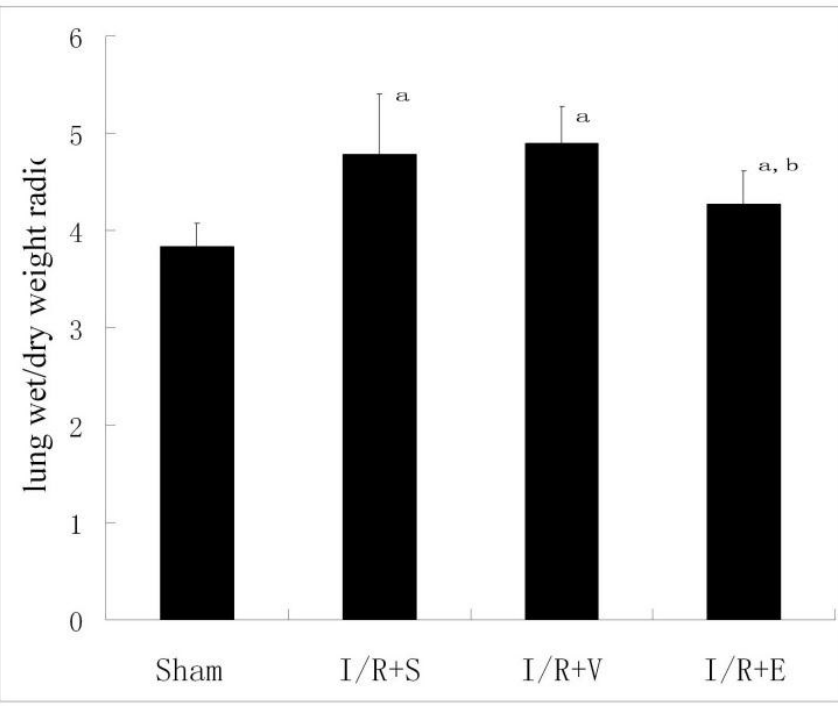

Figure 2: Lung tissue W/D weight ratio $(n=8)$. Emulsified isoflurane suppressed the increases of the lung $W / D$ ratio significantly, while no similar protective effect was observed in NS or lipid vehicle preconditioning. ${ }^{a} \mathrm{p}<0.01$ vs sham group; ${ }^{b} \mathrm{p}<0.05$ vs $\mathrm{I} / \mathrm{R}+\mathrm{S}$ group or $\mathrm{I} / \mathrm{R}+\mathrm{V}$ group.

\section{Pulmonary edema after hepatic I/R}

The lung $\mathrm{W} / \mathrm{D}$ ratio (a parameter of pulmonary edema) increased significantly in the $I / R+S, I / R+V$ and $\mathrm{I} / \mathrm{R}+\mathrm{E}$ groups compared with that in sham group (Fig. 2). Emulsified isoflurane suppressed the increases of the lung W/D ratio significantly, while no similar protective effect was observed in NS or lipid vehicle preconditioning.

\section{Myeloperoxidase (MPO) activity after hepatic I/R}

Neutrophil recruitment in the lung was assessed by measuring tissue MPO content. Lung tissue MPO was low in sham rats $(1.41 \pm 0.51 \mathrm{U} / \mathrm{g})$, but increased to $5.5 \pm 1.37,5.22 \pm 1.33$ and $3.81 \pm 1.62 \mathrm{U} / \mathrm{g}$ in $\mathrm{I} / \mathrm{R}+\mathrm{S}$, $\mathrm{I} / \mathrm{R}+\mathrm{V}$ and $\mathrm{I} / \mathrm{R}+\mathrm{E}$ groups $4 \mathrm{~h}$ after hepatic reperfusion $(\mathrm{P}<0.01)$. MPO activity in $\mathrm{I} / \mathrm{R}+\mathrm{E}$ was significantly lower than that in $\mathrm{I} / \mathrm{R}+\mathrm{S}$ or $\mathrm{I} / \mathrm{R}+\mathrm{V}$ group $(\mathrm{P}<0.05$, Fig. 3).

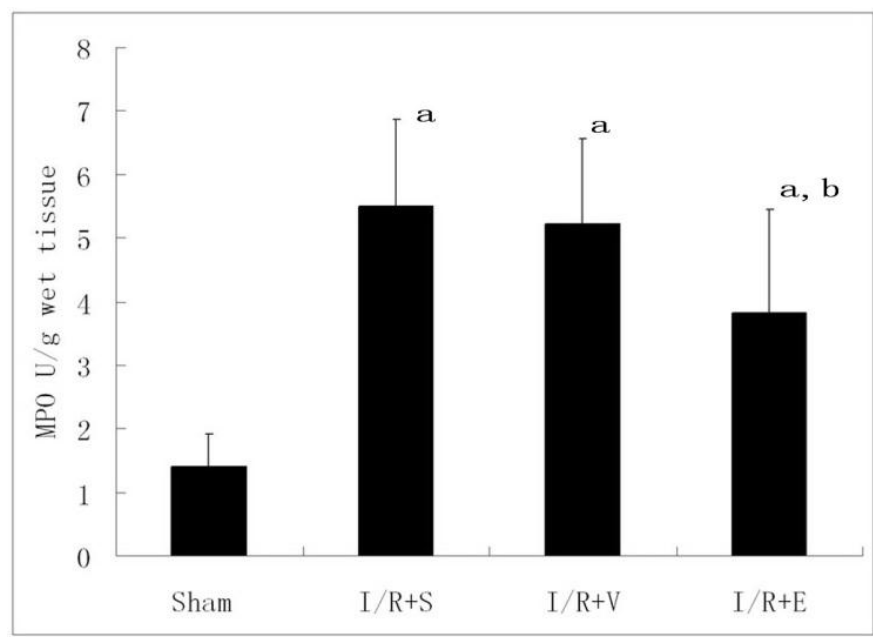

Figure 3: Lung tissue MPO activity $(n=8)$. Lung tissue MPO was low in sham rats and increased in $I / R+S, I / R+V$ and $\mathrm{I} / \mathrm{R}+\mathrm{E}$ groups, while MPO activity in $\mathrm{I} / \mathrm{R}+\mathrm{E}$ was significantly lower than that in $I / R+S$ or $I / R+V$ group. ${ }^{a}$ $\mathrm{p}<0.01$ vs sham group; ${ }^{b} \mathrm{p}<0.05$ vs $\mathrm{I} / \mathrm{R}+\mathrm{S}$ group or $\mathrm{I} / \mathrm{R}+\mathrm{V}$ group.

\section{Lung Tissue and Serum TNF-a level after hepatic I/R}

Compared with sham group, both serum and lung TNF-a levels increased significantly in $I / R+S$, $\mathrm{I} / \mathrm{R}+\mathrm{V}$ and $\mathrm{I} / \mathrm{R}+\mathrm{E}$ groups $4 \mathrm{~h}$ after reperfusion $(\mathrm{P}<0.05)$. Statistic analysis showed that both serum and lung TNF-a levels in I/R+E group were significantly lower than those of $I / R+S$ or $I / R+V$ group $(\mathrm{P}<0.05)$, and there was no significant difference between $\mathrm{I} / \mathrm{R}+\mathrm{S}$ and $\mathrm{I} / \mathrm{R}+\mathrm{V}$ groups $(\mathrm{P}>0.05$, Fig. 4$)$. 


\section{ICAM-1 mRNA expression in lung}

RT-PCR analysis revealed that ICAM-1 mRNA expression was hardly detectable in sham group. However, it was up-regulated markedly in the other three groups (Fig. 5). Compared with I/R+S or I/R+V group, emulsified isoflurane preconditioning reduced ICAM-1 mRNA expression significantly.

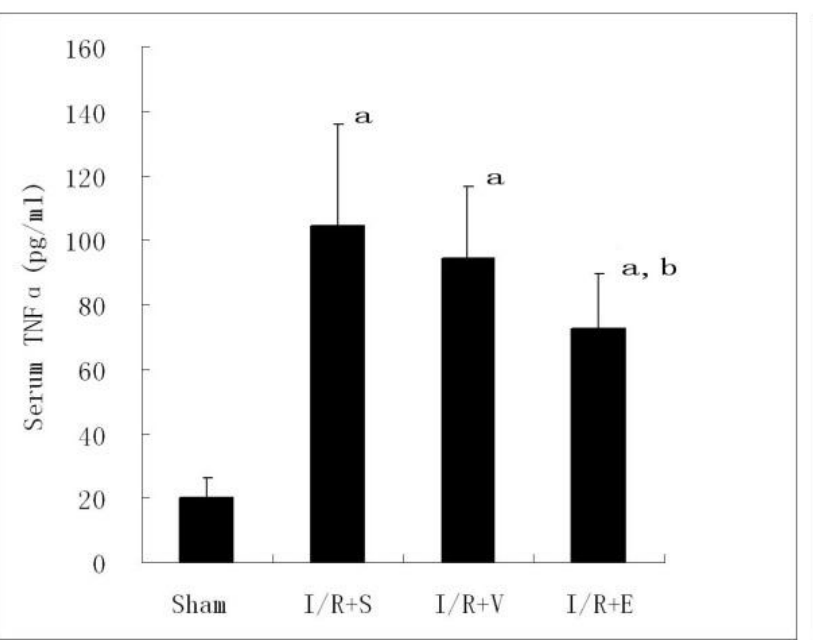

\section{NF-KB activity in lung}

A low level of p65 subunit of NF- $\mathrm{BB}$ was observed in nuclear extracts of the lungs from sham group. As expected, the nuclear localization of p65 increased markedly in $\mathrm{I} / \mathrm{R}+\mathrm{S}, \mathrm{I} / \mathrm{R}+\mathrm{V}$ and $\mathrm{I} / \mathrm{R}+\mathrm{E}$ groups compared with sham group (Fig. 6). As indicated by previous results, p65 expression was significantly reduced by emulsified isoflurane preconditioning, but not by normal saline or lipid vehicle preconditioning $(\mathrm{P}<0.05)$.

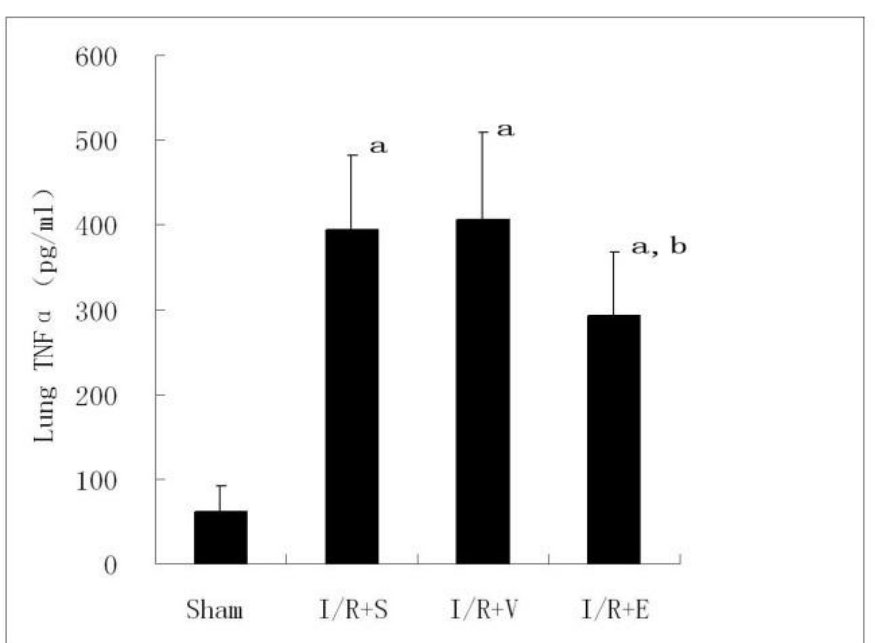

Figure 4: Effects of emulsified isoflurane pretreatment on TNF-a levels in lung tissue and serum after hepatic I/R in rats $(\mathbf{n}=\mathbf{8})$. Compared with sham group, both serum and lung TNF-a levels increased significantly in $I / R+S, I / R+V$ and I/R+E groups. Serum and lung TNF-a levels in I/R+E group were significantly lower than those of $I / R+S$ or $I / R+V$ group. ${ }^{a} \mathrm{p}<0.01 \mathrm{vs}$ sham group; ${ }^{\mathrm{b}} \mathrm{p}<0.05 \mathrm{vs} \mathrm{I} / \mathrm{R}+\mathrm{S}$ group or $\mathrm{I} / \mathrm{R}+\mathrm{V}$ group.

Figure 5: RT-PCR analysis of ICAM-1 mRNA expression in the lung after hepatic I/R $(n=6)$. ICAM-1 mRNA expression was increased markedly in I/R+S, I/R+V and I/R+E groups. Compared with $\mathrm{I} / \mathrm{R}+\mathrm{S}$ or $\mathrm{I} / \mathrm{R}+\mathrm{V}$ group, emulsified isoflurane preconditioning reduced ICAM-1 mRNA expression significantly. ${ }^{a} \mathrm{p}<0.01$ vs sham group; ${ }^{b} \mathrm{p}$ $<0.05$ vs I/R+S group or I/R+V group.
Sham $\quad \mathrm{I} / \mathrm{R}+\mathrm{S} \quad \mathrm{I} / \mathrm{R}+\mathrm{V} \quad \mathrm{I} / \mathrm{R}+\mathrm{E} \quad$ Mark
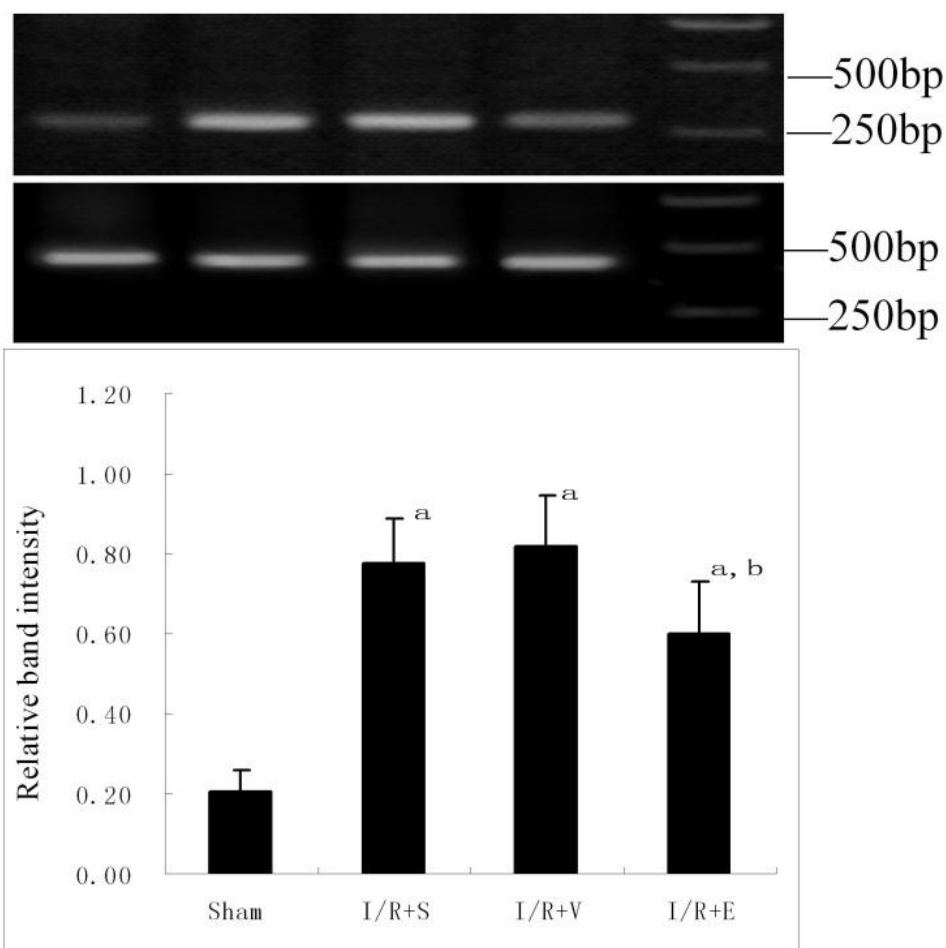


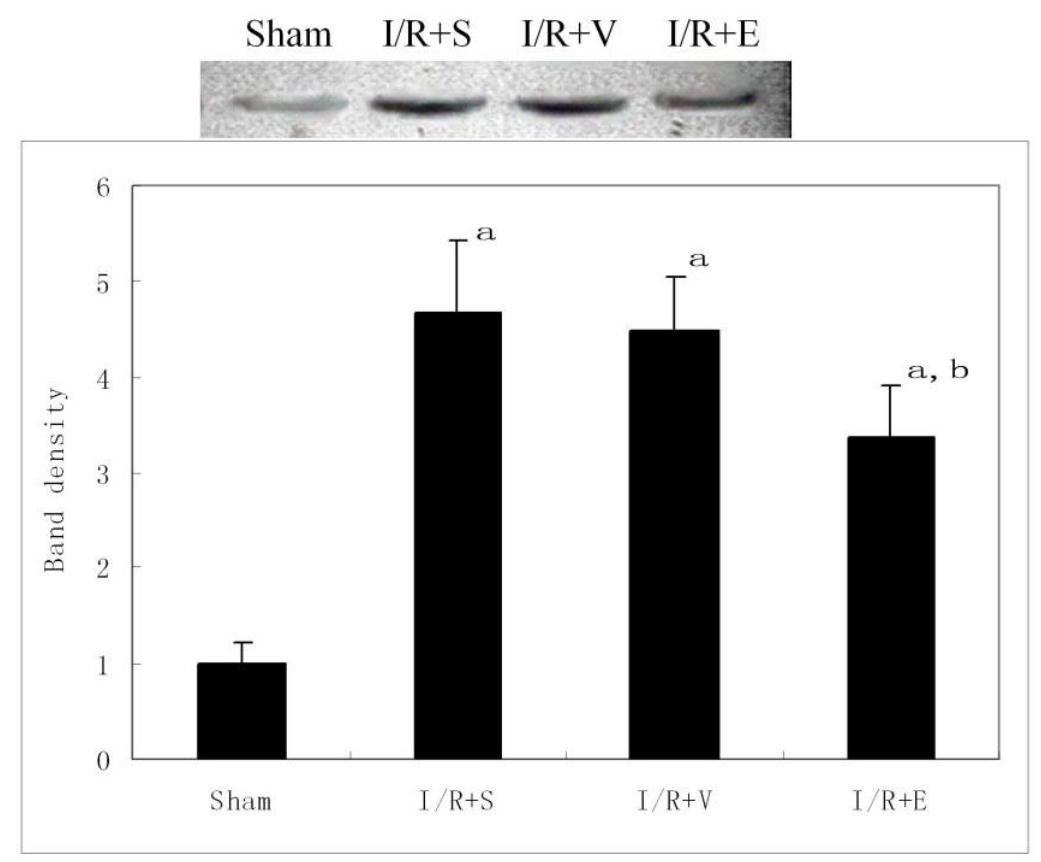

Figure 6: Effects of emulsified isoflurane pretreatment on NF-kB p65 translocation in the lung after hepatic I/R $(n=3)$. The top panel shows Western blot analysis for NF-kB p65 in nuclear protein extracts from the rat lung. The bottom panel shows relative densitometric units. The average expression level of the sham group data was set to 1.0, and other data were adjusted to this baseline. The nuclear localization of $p 65$ increased markedly in $I / R+S, I / R+V$ and $\mathrm{I} / \mathrm{R}+\mathrm{E}$ groups compared with sham group, but it was significantly reduced by emulsified isoflurane preconditioning. ${ }^{\mathrm{a}}$ $\mathrm{p}<0.01$ vs sham group; ${ }^{b} \mathrm{p}<0.05$ vs $\mathrm{I} / \mathrm{R}+\mathrm{S}$ group or $\mathrm{I} / \mathrm{R}+\mathrm{V}$ group.

\section{Discussion}

Ischemia followed by reperfusion injury is associated with a number of clinical disorders, including systemic inflammatory response syndrome (SIRS), multiple organ dysfunction syndrome (MODS) and multiple system organ failure (MOSF). The lung is one of the most important target organs in MODS or MOSF caused by severe injury. It was found that the lung could also be damaged by remote organ injury such as gut and liver I/ $\mathrm{R}$ injury ${ }^{22}$. This process is associated with activation of inflammatory reaction, including the increased activity of NF- $\mathrm{kB}$ and the increased inflammatory mediators such as TNF-a and ICAM-123.

The results of our study showed that 90-min hepatic ischemia followed by 4 -h reperfusion induced significant lung injury, as manifested by evidence of lung edema, PMN infiltration and histological injuries. Moreover, lung injury was associated with inflammation, as indicated by NF-KB translocation, increase of TNF-a levels and MPO activity, and up-regulation of ICAM-1 expression in the lung tissue.

To our knowledge, this is the first study providing the evidence that preconditioning with emulsified isoflurane could attenuate inflammation reaction and ALI induced by hepatic I/R. In the study we used emulsified isoflurane infused at a rate of 8

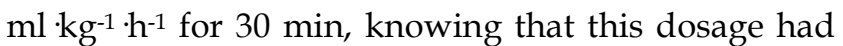
no significant inhibitory effect on circulation in pentobarbital anesthetized rats as shown by previous experiments ${ }^{24}$. Our results showed that emulsified isoflurane preconditioning could reduce lung injury induced by hepatic $I / R$, as represented by decreased NF-KB activity, TNF-a level and MPO activity, and decreased ICAM-1 expression in the lung as well.

Neutrophils are an important component of the inflammatory response that characterizes $\mathrm{ALI}^{25}$. Activated neutrophils, which infiltrate the lungs during endotoxemia, produce cytokines, such as interleukin- $1 \beta$ and TNF- $\alpha$, and play a key role in the development of ALI by releasing neutrophil proteases and reactive oxygen species ${ }^{26}$. Previous studies ${ }^{27-29}$ showed that isoflurane preconditioning could reduce neutrophil accumulation in the myocardium, and that abolishing neutrophils would induce impairment to contractile function in rat hearts in vitro and in vivo. This inhibitory effect of isoflurane on neutrophils was associated with an inhibition on neutrophil superoxide production and adherence to coronary vascular endothelia. In our study, emulsified isoflurane precon- 
ditioning significantly reduced neutrophil accumulation in the lung, which may be associated with the protective effect on the lung.

Lung injury induced by hepatic I/ $R$ is thought of as a result of liver-derived TNF-a. In fact, blockade of TNF-a by antibody neutralization greatly reduced hepatic I/R induced lung inflammatory injury in rats $^{30}$. TNF- $\alpha$ can up-regulate neutrophil adhesion molecules in the liver and remote organs, especially intercellular adhesion molecule-1 (ICAM-1), following hepatic $I / R$, which then plays an important role in tissue neutrophil influx ${ }^{31}$.

Some experiments suggested that ischemic preconditioning was able to exhibit anti-inflammatory and protective effect in some organs in vitro and in vivo. Isoflurane could down-regulate LPS-induced production of pro-inflammatory cytokines, including TNF- $\alpha$ and IL-1 $\beta$ in rats ${ }^{32}$. In this study animals were pretreated with $1.4 \%$ isoflurane for $30 \mathrm{~min}$ before LPS injection. Notably, isoflurane inhalation was associated with a significant reduction of endotoxemia-induced pulmonary TNF- $\alpha$ and IL-1 $\beta$. The similar protective effect was also observed in a rat model of renal I/R injury ${ }^{33}$. Our results showed that emulsified isoflurane preconditioning reduced the serum and lung TNF-a levels and ICAM-1 mRNA expression in lung tissue after hepatic I/R, which may be at least partly contribute to reduced lung injury.

After hepatic ischemia and reperfusion, increased TNF-a level in the circulation initiates a mediator cascade in the lung, including neutrophil infiltration and increased pulmonary vascular expression of intercellular adhesion molecule- 1 . The gene expression of these proinflammatory mediators is controlled at least partly by the transcription factor $\mathrm{NF}-\mathrm{KB}^{34}$.

$\mathrm{NF}-\kappa \mathrm{B}$ is a key transcription factors that plays a key role in inflammatory response and is activated in the lung after hepatic IR. Activation of NF- $\mathrm{kB}$ induced expression of a variety of inflammation-related products, including cytokines, chemokines, and adhesion molecules ${ }^{35,36}$. Increased concentrations of these inflammatory mediators may contribute to lung injury. Previous studies showed that sevoflurane preconditioning and ischemia preconditioning attenuated NF- $\mathrm{KB}$ activation and reduced the expression of inflammatory mediators induced by I/ $\mathrm{R}$ in the heart, thus decreasing myocardial IR injury ${ }^{37}$. It was found in the present study that emulsified isoflurane preconditioning had a similar effect on NF- $\mathrm{KB}$ translocation in the lung. Emulsified isoflurane preconditioning suppressed the activity of NF- $\mathrm{BB}$ significantly and reduced the expression of inflammatory mediators including TNF-a and ICAM-1, both of which contribute to the lung injury after hepatic I/R.

This study, together with previous reports, suggest that emulsified isoflurane preconditioning could ameliorate lung edema and neutrophil recruitment, decrease TNF-a level in serum and lung tissue, and down-regulate ICAM-1 by inhibiting activation of $\mathrm{NF}-\kappa \mathrm{B}$, which played a key role in inflammatory response and is activated in the lung after hepatic IR.

In conclusion, the present study demonstrated that emulsified isoflurane may also be protective in surgery- or trauma- related organ injuries occurring secondary to hepatic I/R. Emulsified isoflurane reduced lung injury induced by hepatic $I / R$, as evidenced by amelioration of lung edema and neutrophil recruitment, decreased TNF-a level in the lung tissue and down-regulation of ICAM-1. Zhang et al ${ }^{38}$ found that emulsified isoflurane preconditioning protected the liver and lung in a rat model of hemorrhagic shock, which might be due to inhibition of cell death and improvement of anti-oxidation in mitochondria. Rao et $\mathrm{al}^{13}$ found that emulsified isoflurane preconditioning reduced myocardial infarct size, plasma lactate dehydrogenase and creatine kinase levels after myocardial ischemia reperfusion in rats as inhaled isoflurane. So we speculate that the protective mechanism of emulsified isoflurane is generalized and not specific to the lung. These results suggest that emulsified isoflurane may prove applicable to the clinical treatment of organ injury caused by hepatic surgery, transplantation or hemorrhagic shock.

\section{Acknowledgements}

The study was supported by the National Natural Science Foundation of China (Grant No. 30700788) and Youth Scholars Foundation of Shanghai Health Bureau (Grant No. 2009Y064).

\section{Conflict of Interest}

The authors have declared that no conflict of interest exists.

\section{References}

1. Casillas-Ramírez A, Mosbah IB, Ramalho F et al. Past and future approaches to ischemia-reperfusion lesion associated with liver transplantation. Life Sci 2006; 79: 1881-1894.

2. Liu DL, Jeppsson B, Hakansson CH et al. Multiple-system organ damage resulting from prolonged hepatic inflow interruption. Arch Surg 1996; 131: 442-447.

3. Murry CE, Jennings RB, Reimer KA. Preconditioning with ischemia: a delay of lethal cell injury in ischemic myocardium. Circulation 1986; 74: 1124-1136.

4. Cason BA, Gamperl AK, Slocum RE et al. Anesthetic-induced preconditioning: previous administration of isoflurane decreases myocardial infarct size in rabbits. Anesthesiology 1997; 87: 1182-1190. 
5. Kersten JR, Schmeling TJ, Pagel PS et al. Isoflurane mimics ischemic preconditioning via activation of K (ATP) channels: reduction of myocardial infarct size with an acute memory phase. Anesthesiology 1997; 87: 361-370.

6. Zheng S, Zuo Z. Isoflurane preconditioning reduces purkinje cell death in an in vitro model of rat cerebellar ischemia. Neuroscience 2003; 118: 99-106.

7. Lee HT, Ota-Setlik A, Fu Y et al. Differential protective effects of volatile anesthetics against renal ischemia-reperfusion injury in vivo. Anesthesiology 2004; 101: 1313-1324.

8. Bedirli N, Ofluoglu E, Kerem M et al. Hepatic energy metabolism and the differential protective effects of sevoflurane and isoflurane anesthesia in a rat hepatic ischemia-reperfusion injury model. Anesth Analg 2008; 106: 830-837.

9. Reutershan J, Chang D, Hayes JK et al. Protective Effects of Isoflurane Pretreatment in Endotoxin-induced Lung Injury. Anesthesiology 2006; 104: 511-517.

10. Plachinta RV, Hayes JK, Cerilli LA et al. Isoflurane pretreatment inhibits lipopolysaccharide-induced inflammation in rats. Anesthesiology 2003; 98: 89-95.

11. Liu R, Ishibe $Y$, Ueda M. Isoflurane-sevoflurane administration before ischemia attenuates ischemia-reperfusion-induced injury in isolated rat lungs. Anesthesiology 2000; 92: 833-840.

12. Mathias LA, Piccinini Filho L, Rittes JC et al. Intravenous isoflurane in lipid emulsion promotes cardiovascular and respiratory stability. Experimental model. Revista Brasileira de Anestesiologia 2004; 54: 656-662.

13. Rao Y, Wang Y, Zhang W et al. Emulsified isoflurane produces cardiac protection after ischemia reperfusion injury in rabbits. Anesth Analg 2008; 106: 1353-1359.

14. Centurion SAR, Centurion LM, Souza MEJ et al. Effects of ischemic liver preconditioning on hepatic ischemia/reperfusion injury in the rat. Transplant Proc 2007; 39: 361-364.

15. Peralta C, Prats N, Xaus $C$ et al. Protective effect of liver ischemic preconditioning on liver and lung injury induced by hepatic ischemia-reperfusion in the rat. Hepatology 1999; 30: 1481-1489.

16. Zhou JX, Luo NF, Liang XM et al. The efficacy and safety of intravenous emulsified isoflurane in rats. Anesth Analg 2006; 102: 129-134.

17. Yang XL, Ma HX, Yang ZB, et al. Comparison of minimum alveolar concentration between intravenous isoflurane lipid emulsion and inhaled isoflurane in dogs. Anesthesiology 2006; 104: 482-487.

18. Reutershan J, Chang D, Hayes JK et al. Protective effects of isoflurane pretreatment in endotoxin-induced lung injury. Anesthesiology 2006; 104: 511-517.

19. Welborn MB 3rd, Moldawer LL, Seeger JM et al. Role of endogenous interleukin-10 in local and distant organ injury after visceral ischemia-reperfusion. Shock 2003; 20: 35-40

20. Smirnova IV, Bittel DC, Ravindra $\mathrm{R}$ et al. Zinc and cadmium can promote rapid nuclear translocation of metal response elementbinding transcription factor-1. J Biol Chem 2000; 275: 9377-9384.

21. Yang J, Li W, Duan M, Zhou Z et al. Large dose ketamine inhibits lipopolysaccharide induced acute lung injury in rats. Inflamm Res 2005; 54: 133-137.

22. Hato S, Urakami A, Yamano T et al. Attenuation of liver and lung injury after hepatic ischemia and reperfusion by a cytokine-suppressive agent, FR167653. Eur Surg Res 2001; 33: 202-209.

23. Okaya T, Holthaus R, Kato A et al. Involvement of the neuropeptide substance $P$ in lung inflammation induced by hepatic ischemia/reperfusion. Inflamm Res 2004; 53: 257-61.

24. Hu ZY, Liu J. Effects of emulsified isoflurane on haemodynamics and cardiomyocyte apoptosis in rats with myocardial ischaemia. Clin Exp Pharmacol Physiol 2009, 36: 776-783
25. Abraham E. Neutrophils and acute lung injury. Crit Care Med 2003; 31(Suppl): 195-199.

26. Parsey MV, Tuder R, Abraham E. Neutrophils are major contributors to intraparenchymal lung IL-1 expression after hemorrhage and endotoxemia. J Immunol 1998; 160: 1007-1013.

27. Hu G, Salem MR, Crystal GJ. Isoflurane and sevoflurane precondition against neutrophil-induced contractile dysfunction in isolated rat hearts. Anesthesiology 2004; 100: 489-497.

28. Hu G, Salem MR, Crystal GJ. Role of adenosine receptors in volatile anesthetic preconditioning against neutrophil-induced contractile dysfunction in isolated rat hearts. Anesthesiology 2005; 103: 287-295.

29. Hu G, Vasiliauskas T, Salem MR et al. Neutrophils pretreated with volatile anesthetics lose ability to cause cardiac dysfunction. Anesthesiology 2003; 98: 712-718.

30. Colletti LM, Remick DG, Burtch GD et al. Role of tumor necrosis factor- $\alpha$ in the pathophysiologic alternations after hepatic ischemia/reperfusion injury in the rat. J Clin Invest 1990; 85: 1936-1943.

31. Colletti LM, Cortis A, Lukacs $\mathrm{N}$ et al. Tumor necrosis factor up-regulates intercellular adhesion molecule 1, which is important in the neutrophil-dependent lung and liver injury associated with hepatic ischemia and reperfusion in the rat. Shock 1998; 10: 182-191.

32. Li QF, Zhu YS, Jiang $\mathrm{H}$ et al. Isoflurane preconditioning ameliorates endotoxin-induced acute lung injury and mortality in rats. Anesth Analg 2009; 109: 1591-1597

33. Hashiguchi $\mathrm{H}$, Morooka $\mathrm{H}$, Miyoshi $\mathrm{H}$ et al. Isoflurane protects renal function against ischemia and reperfusion through inhibition of protein kinases, JNK and ERK. Anesth Analg 2005; 101: 1584-1589.

34. Wang Y, Schmeichel AM, Iida $\mathrm{H}$ et al. Enhanced inflammatory response via activation of NF-kappaB in acute experimental diabetic neuropathy subjected to ischemia-reperfusion injury. J Neurol Sci 2006; 247: 47-52.

35. Yoshidome H, Kato A, Edwards MJ et al. Interleukin-10 inhibits pulmonary NF-kappaB activation and lung injury induced by hepatic ischemia-reperfusion. Am J Physiol 1999; 277: 919-23.

36. Colletti LM, Cortis A, Lukacs $\mathrm{N}$ et al. Tumor necrosis factor up-regulates intercellular adhesion molecule 1 , which is important in the neutrophil-dependent lung and liver injury associated with hepatic ischemia and reperfusion in the rat. Shock 1998; 10: 182-91.

37. Zhong C, Zhou Y, Liu H. Nuclear factor kappaB and anesthetic preconditioning during myocardial ischemia-reperfusion. Anesthesiology 2004; 100: 540-545.

38. Zhang L, Luo N, Liu J et al. Emulsified isoflurane preconditioning protects against liver and lung Injury in rat model of hemorrhagic shock. J Surg Res, 2011; doi:10.1016/j/jss.2010.06.037. 